\title{
Presbyterians and conscience ${ }^{1}$
}

\author{
Eric McKimmon
}

Rev Eric McKimmon is a retired Church of Scotland minister living in Cupar, Fife.

This essay explores the role of conscience in the history of Scottish and Irish Presbyterianism. In the Westminster Confession, we find the seminal statement 'God alone is Lord of the conscience'. The framers of the Confession considered the subject important enough to merit an entire chapter: "Of Christian Liberty and Liberty of Conscience". In the eighteenth century, the rights of conscience were a factor in various secessions from the Kirk. However, in the nineteenth century, renewed focus on conscience gave impetus to a search for unity. This trend was again most marked in the secession traditions, resulting in the formation of the United Presbyterian Church in 1847. The UP Church gave conscience a new status in regard to subscription to subordinate standards and pioneered a middle way between doctrinal commitment and personal freedom.

In the Presbyterian Church in Ireland - formed in 1840 - the principle that 'God alone is Lord of conscience' is acknowledged in the Rule of Faith,$^{2}$ but to what extent the statement qualifies subscription to the doctrines of the Confession remains unclear. My interest in the subject of conscience received new urgency in the summer of 2018. As a minister, first in Ireland and afterwards in Scotland, I was sad to hear of the decisions by the General Assembly of the Presbyterian Church in Ireland to, in effect, suspend fellowship with the Church of Scotland. Wrestling with the historical anomaly and spiritual enormity of it all, I stumbled upon conscience as a possible salve for the great wound that had appeared in the Presbyterian family. A better understanding of conscience may help us accommodate our differences and help us renew fellowship. Also, within the Presbyterian Church, letters in the press indicate that disagreements over same-sex relations are a source of ongoing alienation and hurt. Here 
too, respect for conscience would greatly alleviate fear and help the process of reconciliation.

The Oxford Dictionary describes conscience as: 'a person's moral sense of right and wrong, viewed as acting as a guide to one's behaviour'. This echoes the view that has pertained historically within Presbyterianism. The Scottish Presbyterian philosopher Henry Calderwood, in his Handbook of Moral Philosophy, first published in 1872 and which had run to its sixteenth edition in 1891, describes conscience as 'an authoritative voice within the soul - the representative of Divine authority'. ${ }^{3}$ Calderwood belonged with the 'intuitive school' in Scottish philosophy holding that conscience has immediate knowledge of the moral law. The New Testament scholar F. F. Bruce also pointed to the connection between conscience and the moral law in the New Testament.

The word 'conscience' (suneidessis) belonged to the vernacular tongue and attained literary status only a short time before the beginning of the Christian era. It meant 'consciousness of right or wrong doing', ${ }^{4}$ but Paul uses it (and perhaps he was the first to do so) of an independent witness within, which examines and passes judgement on a man's conduct. In a Christian, this examination and judgement is enlightened by the Holy Spirit. $^{5}$

The etymology of a word is valuable as a starting point. But once an idea is launched upon the tide of time, it grows and develops. Conscience has been expanded by usage and context and has come to mean many things in the wide landscape of Christian history and literature. ${ }^{6}$ In the early church, the theologian Ambrose of Milan spoke of the human heart as a large house and it is in the heart that we should converse with conscience as a trusted companion. Clement of Alexandria said conscience gives us a sense both of self and of God. Jerome had a more severe view of conscience: as God's executioner on the last day. Calvin, too, emphasised conscience as that which brings home a sense of divine judgement. On the other hand, Luther considered conscience the harbinger of moralism and of legalism. Conscience is the devil's instrument that tempts the soul away from the grace and freedom that is in Christ. In the Roman Catholic tradition, John Henry Newman famously said he would toast conscience first and the Pope second! The papal encyclical Veritatis Splendor by John Paul II (1993) teaches that conscience for the Christian is not merely a matter of submitting to ethical teachings; conscience brings us into a relationship with Christ and leads to conformity with Christ 
through becoming a member of his Church and through the grace of the Holy Spirit working in our lives. This is but a snapshot of conscience as understood within Christian tradition. Paul Strohm's short and readable book, Conscience: A Very Short Introduction, ${ }^{7}$ gives a good guide as to how conscience has been understood in many cultures.

\section{The Westminster Assembly}

The emphasis given to conscience in the Westminster Confession reflects political circumstances at its time of writing. The background was one of war, engulfing Britain and Ireland. In 1643 Scots and English Parliamentarians agreed a Solemn League and Covenant which led to the calling of the Westminster Assembly in the hope of reaching an overarching settlement in matters of church government, doctrine and liturgy for England and Scotland. On the original roll of the Assembly, there were 121 clergymen. In addition, there were 30 lay assessors. Later, Scottish commissioners were added. They comprised of five ministers and two elders. Though small in number their influence on the Assembly was significant. Irish Anglicans had a voice through the presence of James Ussher, Archbishop of Armagh. The lasting monument to the Westminster Assembly is the Westminster Confession of Faith, which Presbyterian denominations around the world variously honour; either as an historic landmark or as a present statement of doctrine.

The Confession has thirty-three chapters. Chapter Twenty is headed, "Of Christian Liberty and Liberty of Conscience".

Section I outlines the essential liberty of the Christian. It is spiritual freedom from fear, sin, judgement, and death and freedom of access to God through 'a child-like love and a willing mind'. In an otherwise scholastic document, this a warm devotional expression.

Section II affirms 'God alone is Lord of the conscience'. In consequence, there is freedom 'from the doctrines and commandments of men' and from 'anything contrary to [God's] Word, or beside it, in matters of faith, or worship'. There is no place for unquestioning faith: 'the requiring of an implicit faith and an absolute and blind obedience is to destroy liberty of conscience, and reason also.'

Section III has a warning note: to cherish, or practise, sin and lust, endangers freedom. God delivers us from all enemies of the soul so that we may live and serve 'without fear.' 
The final section, IV, has the marks of the Confession's historical setting. The Assembly of divines feared that freedom might become chaos. Christian liberty might pull things down rather than build them up. Outside the Assembly, the divines mingled with radicals, Levellers, antinomians, millenarians, Quakers and others. Cromwell's army had some of the most radical voices. In this context, the divines approved state intervention in spiritual matters. Anyone acting against peace and order may be 'proceeded against by the censures of the church, and by the power of the civil magistrate'. This edict would cast a long shadow in Scotland where the sustained persecution of witches (mostly women) was barbaric. It would take a long time before freedom of conscience in the modern sense would become the norm. Yet, it is all the more remarkable that, within the moral and spiritual constraints of their time, the Westminster divines articulated an enduring principle: 'God alone is Lord of the conscience'.

Several factors played a part in the Assembly's attention to Christian liberty. First, the diversity of the members of the Assembly itself. Theologically, there were in their number high Calvinists; supralapsarians who believed that God from all eternity ordained both the fall and redemption; there were infralapsarians who believed that divine election was God's response to the fall; yet others were hypothetical universalists who believed that, though Christ died for the elect, the benefits of his atonement were, in principle, available to any who should believe. The Assembly was theologically diverse.

Differences as to an ecclesiastical settlement also divided the Assembly. Some advocated an Erastian outcome - in other words, a church governed by the state, modelled on ancient Israel; ${ }^{8}$ the majority favoured a Presbyterian polity, with varying degrees of state involvement; and a substantial section of the divines were independents, advocates of a congregational system of church government. Cromwell's sympathies lay with the independents. Only if liberty of conscience were allowed, could many sects and factions be accommodated within one Christian commonwealth. In the end, it was in Scotland that the blueprint for a Presbyterian system of church government became established law. In England, there was what has been called a 'confederacy of sects'. Alongside this confederacy, Anglicans, Catholics and Quakers continued to be persecuted. The spirit of tolerance within the walls of the Westminster Assembly was something of a haven amidst turbulent times. 
Liberty of conscience for the Westminster Assembly was, therefore, to a large extent functional and practical; and yet, perhaps neither of these reaches the heart of the matter. For Puritans, conscience is essentially a spiritual faculty. Geoffrey F. Nuttall, in his study The Holy Spirit in Puritan Faith and Experience, ${ }^{9}$ catalogues the intensity of debate in puritanism of all hues as to the spiritual centrality of conscience. Obviously, having left the security of the Catholic magisterium, the quest for spiritual foundations was urgent. Authority came to be vested in a broad family of spiritual norms: Scripture, reason, experience (the light of nature), and conscience: each in their own way channels for the grace of the Holy Spirit. The literature of the period indicates how puritans engaged with the issues. It is difficult to detect a settled hierarchy in this family of norms. Preachers and pamphleteers of the period are distinguished by their various emphases. But we can detect in them all an acknowledgement of the inner working of the Holy Spirit. William Dell (1607-1669), chaplain to the New Model Army, wrote: 'They who preach the Outward Letter of the Word, though never so truly, without the Spirit, do ... wholly mistake the Mind of Christ in the Word for want of the Spirit'. ${ }^{10}$ Puritan Thomas Goodwin, member of the Assembly, linked the Spirit to the inner light of conscience: 'Natural conscience sees very far and is as "the candle [of the Lord searching the inner most parts]" Prov. Xx.27; but the Spirit's conviction goes and searches far beyond it.' ${ }^{11}$ Reason was also considered foundational. Presbyterian, Richard Baxter wrote: 'the Spirit worketh not on the will but by the reason; he moveth not a man as a beast or stone, to do a thing he knoweth not why, but by illumination giveth him the soundest reason for the doing of it. ${ }^{12}$ Samuel Rutherford, one of the Scottish commissioners, took a more restrictive view as to the authority of conscience. In his Free Dispensation Against Pretended Liberty of Conscience, ${ }^{13}$ written in 1649, Rutherford states the object of conscience 'can be nothing but God's revealed will expressed to us, either in the Law of Nature, or in the Law written, or the Gospel. ${ }^{14}$ In the same monograph he writes: 'the Word of God must be rule of conscience, and conscience is a servant, and an under-judge only, not a Lord'. ${ }^{15}$ Not unsurprisingly, Rutherford concludes that toleration has no warrant in Scripture. ${ }^{16}$ John Milton protested that the 'new Presbyter' was but 'old Priest writ large'. ${ }^{17}$ Yet, Rutherford could also speak of the need for humility and compassion. 
We cannot think but all Saints this side of glory carry to heaven with them errors mistakes and prophesying in part [...]. And here brotherly indulgence and reciprocation of the debt of compassionate forbearance of the infirmities of one another must have place. $^{18}$

The tension between dogmatic theology and spiritual generosity that we find in Rutherford was mirrored in the Assembly. The independents and puritans favoured the rights of conscience and toleration; whilst the Scots favoured conformity in church and state. One of the main achievements of the Assembly was to hold together contrary convictions under the rubric of Christian liberty. William Beveridge commented that, though these seventeenth-century divines did not understand conscience as it is understood today, we 'must be ever thankful that they sounded a note which went farther than they knew'. ${ }^{19}$ Beveridge was writing in 1904.

\section{The nineteenth and twentieth centuries}

In the late nineteenth century, the United Presbyterian Church gave freedom of conscience a status not hitherto enjoyed. Through the leadership of John Cairns (1818-1892) the UP Church was the first Presbyterian body in the world to modify its relation to the Westminster Confession of Faith. In 1879, the United Presbyterian Synod unanimously approved a Declaratory Act. This measure was an historical milestone revising the teaching of the confession on several points. ${ }^{20}$ The celebrated 'conscience clause', allowing for liberty of opinion on points of doctrine not entering the substance of the faith, remains relevant to elders and ministers when they sign the required formula of subscription at ordination. The United Presbyterian initiative was followed by a similar act in the Free Church in 1892; and the re-united Church of Scotland, in 1929, incorporated these Declaratory Acts.

Cairns had invaluable support from his ministerial colleague and philosopher Henry Calderwood (1830-1897). In relation to conscience, Calderwood's views echoed those of St Thomas Aquinas. Conscience cannot be wrong in principle, only in application. Such a view, in effect, makes conscience sovereign in matters of belief and morals. John Oman (1860-1939), a pupil of Cairns in theology and Calderwood in philosophy, rejected the naïve realism characteristic of the intuitive school. Oman 
argued that conscience is shaped by experience and, therefore, genuine morality is always interim. "As we for ever hunger and thirst after righteousness, and not as we accept a code of accepted moral imperatives, are we truly conscientious'. ${ }^{21}$ Oman's theology affirmed the value of personality, the relational nature of grace, and the importance of personal insight into truth. Conscience is sovereign, but never static. Cairns and Calderwood in Scotland, and Oman in England, shifted the emphasis from doctrinal orthodoxy to a personal appropriation of faith.

With respect to Ireland, in a most recent study by Andrew R. Holmes, The Irish Presbyterian Mind, ${ }^{22}$ we have an overview of the conservative ethos of the Presbyterian Church in Ireland from its creation, through the merger of the Synod of Ulster with the Secession Synod in 1840. Conservatism, however, was not monolithic - there were always reforming initiatives. John Thompson, Professor of Systematic Theology at Union College, Belfast, catalogued some of these initiatives in an essay written in $1992 .{ }^{23} \mathrm{He}$ recalls how, at various points in the twentieth century, attempts were made in the Irish General Assembly to allow for greater freedom of conscience in the matter of subscription to the Westminster Confession. Attempts were made in 1927, 1968 and 1979 to give more freedom to ministers and elders through alteration of the formula of subscription. These were unsuccessful. An interesting anomaly is the former Presbytery of Munster, which joined the General Assembly in 1854 - there, the minister or elder elect was required to write out a personal declaration of 'acceptance' of the confession of faith, rather than subscribe to it.

These initiatives to modify subscription throughout the church were opportunities to create more spiritual space for conscience; to emulate the spirit of the Westminster divines themselves. Freedom of conscience in the Presbyterian Church in Ireland has remained more of a shibboleth than a reality. ${ }^{24}$ In cultural Presbyterianism, conscience has been invoked as part of anti-Catholic rhetoric. The belief was that Presbyterians obey their conscience and Catholics obey the priest. But things have changed; changed utterly in modern Ireland. In referenda, the population of the Irish Republic has gone against the moral advice of Catholic bishops, approving same-sex marriage and the introduction of abortion legislation. Presbyterians can make no claim to be the custodians of freedom of conscience. Within Irish Presbyterianism, the sub-narrative of respect for 
conscience needs the breath of life, the renewing power of the Spirit of Christ.

\section{Practical implications}

If Irish Presbyterians could retrieve this valuable strand in their heritage respect for personal freedom and conscientious conviction - it would enable the repair of some bridges that have been broken. Take first the broken relationship with the Kirk - there are undoubted differences of theological emphasis in this extended Presbyterian family. Which healthy family does not have difference? Difference in the past has been bridged by bonds of affection and mutual service. When the Synod of Ulster and the Secession Synod were drawing up a plan of union in 1840, Henry Cooke, leader of evangelicals in the church, made it clear that the union must not endanger relationships with what he called 'the mother church'. $\mathrm{He}$ intimated that if in the terms of union anything ungracious or disrespectful towards the mother Church of Scotland should be insisted upon, he would vote against the proposed union' ${ }^{25}$ This bond of affection, so precious to Cooke, has been strong right up until very recently. The two churches have always had a helping and enabling relationship. During the Troubles, Scottish ministers came to Northern Ireland on parish exchanges, to give welcome relief to hard-pressed Irish colleagues. In the matter of education for the ministry, students from Ireland have gone to study in Scottish faculties of theology for generations. In terms of parish ministry, for the latter part of the twentieth century, ministers enjoyed 'mutual eligibility' with respect to ministry in either Scotland or Ireland. It was an arrangement that the Church of Scotland suspended in 2003, and perhaps this was a straw in the wind. Another, ominous sign was the refusal of the Presbyterian Church in Ireland to join in the creation of a $4^{\text {th }}$ edition of the Church Hymnary.

If bonds of friendship and mutual service are to be restored, it will not be through the two churches becoming a pale copy of each other. We have always been a mixed bag of theological perspectives. One hope for restoration and healing lies in the conscience principle. In particular, can sincere and conscientious views about human sexuality be brought under the canopy of mutual respect and understanding? The Church of Scotland has already placed the issue there; this has saved the Kirk from any major 
schism. Can the same respectful latitude be applied so that our historic friendship is restored?

\section{Conscience and Scripture}

It is a myth to think that in Presbyterianism - or in Christianity generally - there is one unambiguous, timeless, reading of the Bible. The revision, or re-visioning, of the message of Scripture is part of Presbyterian heritage. For example, both the Church of Scotland and the Presbyterian Church in Ireland have abandoned biblical literalism with regard to the ordination of women. The decision to ordain women was a prophetic revision of the teaching of Scripture. The principle is in Scripture itself. Jesus said: 'I still have many things to say to you, but you cannot bear them now. When the Spirit of truth comes, he will guide you into all truth' (John 16:12-13a). God is not dead; the Spirit speaks, corrects and guides. Prophetic revision means that sometimes what was always done may be done no more; and what was never done may be done for the first time. The Westminster Confession teaches 'the purest Churches under heaven are subject both to mixture and error' (25.v). However, historically, churches have been keen to champion their truth and reluctant to admit to error. Christianity in essence is not faith in a book, or text, or interpretation of a text; but in the crucified and risen Lord. And even Christ-focused faith may be smothered in self-serving piety unless faith's eschatological perspectives are ever respected.

Christ is an eschatological figure; always before us; and the doctrine of his 'coming again' with glory implies that there are dimensions of his Christhood not manifest in the historical Jesus and not yet fully grasped by his disciples. ${ }^{26}$

\section{Conscience and church}

The honouring of conscience, our own conscience and the conscience of others, has important implications for every relationship. Where conscience is respected, there is contrition for past failures, together with joyful openness to thought and love. Where respect is absent, we create an incestuous, intellectual atmosphere, where everyone thinks the same; or we frame a hostile spiritual environment, where people are afraid to express their opinion. 
Attitudes to sexuality are a case in point. Same-sex relationships have been historically castigated and, even today, marginalised. May we not see same-sex relationships as a sign of the kingdom of God in people's lives? As the late Fr Seán Fagan wrote over twenty years ago in his book, Does Morality Change?, ${ }^{27}$ Paul had no knowledge of homosexuality as we know it; he thought of it as a perversion and identified it with Temple prostitution. Today, we see gay and lesbian people as having the same need for sexual love as straight people. Sexual orientation in a loving, committed relationship is a gift to be celebrated. Fr Fagan suffered censure from church authorities but the Catholic people of Ireland heard and recognised in his writings the voice of the Good Shepherd. The inclusive way is not an easy way. Where there is conviction, there is always a cross; the cross of loving a sister or brother who also loves Christ and takes a contrary view (Galatians 6:2).

An inclusive spirit will shape the ways in which the church thinks about baptism and the Lord's Supper: are they good conduct prizes and badges of identity for the righteous, or are they material expressions of the gospel, communicating sacramentally the glad tidings of God's love, for all of humanity? A Church of Ireland minister on the radio described Holy Communion as 'holy hospitality'. I think this is the heart of the matter. Exclusion from the sacramental life of the church was once the main tool of discipline in Presbyterianism. It would be sad, and in my opinion a sin, if this discipline were resurrected and directed against the gay and lesbian members. Alas, this is the discipline agreed by the General Assembly of the Presbyterian Church in Ireland in 2018. Would the Good Shepherd have pastors of the flock identify and discriminate sacramentally against people on the grounds of their sexuality? Is it in the spirit of Jesus, who taught us to love each other in our otherness, to penalise the expression of the love that once upon a time couldn't name its name? The conscience of the least of Christ's sisters and brothers is important and needs to be heard in any church that aspires to be a truly Christ-like community. 


\section{Notes}

1 This is an abridged form of a lecture given in Christ Church Rathgar, Dublin on $28^{\text {th }}$ March 2019. It was part of a series of lectures entitled Faith in Conversation.

2 The Rule of Faith is read at Ordinations in the Presbyterian Church in Ireland. See Book of Public Worship of the Presbyterian Church in Ireland, published by the authority of the General Assembly, 1965.

3 Henry Calderwood, Handbook of Moral Philosophy, $16^{\text {th }}$ ed. (London: Macmillan, 1891), 65.

4 A Greek-English Lexicon, compiled by Henry George Liddell and Robert Scott, $9^{\text {th }}$ ed. (Oxford: Clarendon Press, 1940).

5 F. F. Bruce, The Epistle of Paul to the Romans: An Introduction and Commentary (London: Tyndale Press, 1963), 91.

6 See summary in Oliver O'Donovan, The Ways of Judgement: The Bampton Lectures, 2003 (Grand Rapids, Mich.: William B. Eerdmans, 2005), 301-05.

7 Paul Strohm, Conscience: A Very Short Introduction (Oxford: Oxford University Press, 2011).

8 Named after Swiss physician and Zwinglian theologian, Thomas Erastus (1524-1583).

9 Geoffrey F. Nuttall, The Holy Spirit in Puritan Faith and Experience (Chicago: University of Chicago Press, 1992).

10 Ibid., 22.

11 Ibid., 38.

12 Ibid., 47.

13 Samuel Rutherford, A Free Disputation Against Pretended Liberty of Conscience (London: Andrew Crook, 1649).

14 Ibid., 8.

15 Ibid., 10.

16 Ibid., 145.

17 John Milton, "On the New Forcers of Conscience under the Long Parliament".

18 Rutherford, Free Disputation, iii f.

19 William Beveridge, A Short History of the Westminster Assembly (Edinburgh: T\&T Clark, 1904), 115.

20 The Act affirmed that: the universal love of God is available to all humankind; the eternal decrees do not preclude the offer of the gospel 
to all; human depravity does not mean men and women cannot perform good actions; those who have never heard the gospel are not necessarily lost, neither are those who die in infancy; the church disapproves of 'all compulsory or persecuting and intolerant principles in religion' and allows liberty of opinion on such points of doctrine not of the substance of the faith.

21 John Oman, Grace and Personality (Cambridge: Cambridge University Press, 1917), 103.

22 Andrew R. Holmes, The Irish Presbyterian Mind: Conservative Theology, Evangelical Experience and Modern Criticism, 1830-1930 (Oxford: Oxford University Press, 2018).

23 John Thompson, "The Westminster Confession in the Presbyterian Church in Ireland", in The Westminster Confession in the Church Today, ed. Alasdair I. C. Heron (Edinburgh: Saint Andrew Press, 1982), 90-94.

24 The Non-Subscribing Presbyterian Church in Ireland, dating to 1725 and constituted in 1910, represents a liberal theological tradition forgoing all subscription to subordinate standards.

25 W. D., in The General Assembly of the Presbyterian Church in Ireland 1840-1990: A Celebration of Irish Presbyterian Witness During a Century and a Half, ed. R. F. G. Holmes and R. Buick Knox (Belfast: The Presbyterian Historical Society of Ireland, 1990), 10. John Macquarrie, Three Issues in Ethics (London: SCM, 1970), 109.

27 Seán Fagan, Does Morality Change? (Dublin: Gill and MacMillan, 1997), 60 . 